\title{
The Analysis of the Problem of Economic Mathematical Problems Reversed from the Ability of Logic Thinking in Students
}

\author{
Wahyuddin \\ University of Muhammadiyah Makassar, Makassar, South Sulawesi, INDONESIA
}

\begin{abstract}
This study aims to determine the level of logical thinking skills of solving ability on math problem of the economy, and the effect on the ability of logical thinking ability in solving mathematical economics at Mathematics Education students Muhammadiyah University Makassar. This research is an ex-post facto nature of causality with total population were 245 people from 8 different classes. Samples invoved 58 students consisting of 2 classes using a sampling technique. The research instrument consists of logical thinking ability test as many as 30 items and problem solving test ability by 5 items were valid and reliable before use. Data were analyzed using descriptive and inferential statistics (correlation and regression analysis). The research findings shows that: (1) The ability to think logically masiswa are in good enough category with an average value of 69.13 ; (2) The level of mathematical problem solving ability for masiswa economy is in the category quite well with the average value of 74.03; (3) The level of logical thinking ability masiswa correlated with mathematical problem solving ability with great economy of $94.5 \%$ relationship where that is located on a well once; and (5) the ability to think logically positive effect on the ability of solving problems with the effect of $89.1 \%$ while the remaining $10.9 \%$ is influenced by other variables outside the model. On conslusion, the ability to think logically positive effect on the ability of settlement capability, it can be concluded that the higher of logical thinking skills possessed by the student means the student problem-solving abilities are higher.
\end{abstract}

KEYWORDS

Logical Thinking Skills, Problem Solving Ability, Mathematical Economics
ARTICLE HISTORY

Received 11 March 2017

Revised 19 May 2017

Accepted 14 July 2017

\section{Introduction}

Based on law Number 14 Year 2005 regarding Teachers and Lecturers Teachers are required to have academic qualifications, competencies, certificates of educators, physically and mentally healthy, and have the ability to reach the

\section{CORRESPONDENCE Wahyuddin wahyu@unismuh.ac.id}

(c) 2017 Wahyuddin.

Open Access terms of the Creative Commons Attribution 4.0 International License apply. The license permits unrestricted use, distribution, and reproduction in any medium, on the condition that users give exact credit to the original author(s) and the source, provide a link to the Creative Commons license, and indicate if they made any changes. (http://creativecommons.org/licenses/by/4.0/) 
goals of national education. Teachers' competence as referred to in Article 8 covers pedagogic competence, personality competence, social competence, and professional competence obtained through professional education.

Considering that mathematics education students are mathematics teacher candidates who in the future will act as educators and teachers of mathematics, mathematics education students must also be prepared to master the four competencies of teachers in question before they become actual teachers. Students of mathematics as well as teacher candidates have an important role in determining future success in achieving their students' learning outcomes, so that students of mathematics teacher candidate need to be equipped with sufficient experience and better knowledge.

The Committee on the Undergraduate Program in Mathematics (CUPM, 2004) recommends mathematics and math courses, as well as mathematics teacher candidates covering six important recommendations for the development of mathematics learning, each lecture should involve activities that can help advance students in developing thinking Anilitic, critical reasoning, problem solving, and communication skills and accustomed to mathematical thinking; Presents key ideas and concepts from multiple perspectives; Using examples and broad application to motivate and illustrate the material; Promoting awareness of mathematical links with other subjects of mathematics or outside mathematics; Introducing contemporary topics of mathematics and its application, and enhancing students' perceptions of the importance of mathematics in the modern world.

Furthermore, especially for math teacher candidates, CUPM (2004) recommends that lectures can help students to develop: (1) solid knowledge at the top level; (2) Mathematical thinking and communication skills, including knowledge of various explanations and examples, good quantitative and logical thinking skills in separating and reconnecting component parts of concepts and methods; (3) Understanding and experience with the use of mathematics in various fields; And (4) Knowledge, confidence and motivation to pursue the development of professional mathematics for a long-term career.

From these recommendations, it can be concluded that the student of teacher candidate must be equipped with a number of competencies such as mathematical abilities, deep and comprehensive understanding of content and especially process process capability, logical.

The ability to solve problems is very important in mathematics, not only for those who will later learn or study mathematics, but also for those who will apply it in other fields of study and in everyday life (Russefffendi, 2006). The ability to solve mathematical problems is a skill in learners to be able to use mathematical activities to solve problems in mathematics, problems in other sciences and problems in everyday life. Sumarmo (2000) argues that problem solving is a process to overcome difficulties encountered to achieve a desired goal.

The National Council of Teachers of Mathematics sets the problem-solving as a goal and approach. Solving a meaningful problem answers a question where the method for finding the solution of the question is not known in advance. To find a solution, students must use the things they have learned before and 
through the process by which they will develop new mathematical understandings. Solving problems is not only an objective of learning mathematics but also a major tool for learning (NCTM, 2000).

The ability to solve problems is the ability that is needed by students. Sumarmo (2000) argued that, problem solving is a process to overcome difficulties encountered to achieve a desired goal. Problem solving ability can be grown through problem solving activities. This is to facilitate students in relating the knowledge gained with experience. If the problem is not related to the student experience, then they may not necessarily understand the problem well studied. Problem solving should always be familiarized for students in order to achieve the desired goals. However, a student will not be able to solve a problem which is given to him/her if he/she has no previous concepts required. The importance of problem-solving ability is also found by Soedjadi (in Kisworo, 2000 ), that the success of a person in his life is largely determined by the ability to solve the problems he faces.

Problem solving as one aspect of high-level thinking ability. Polya states that problem solving is a very high level of intellectual activity. Problem solving

is an intellectual activity to solve problems encountered by using the provision of existing knowledge. This opinion is supported by Branca's statement (Sumarmo, 1994) that problem-solving abilities are common goals in mathematics courses, even as the heart of mathematics, meaning that problem-solving skills are the basic abilities of a mathematics lecture.

According to Jhon (2008: 5), the problem solving indicator is: a) Building mathematical knowledge through problem solving; B) Solve problems that arise in mathematics; C) Implement and adapt various strategies suitable for solving problems; And d) Observe and develop the process of solving mathematical problems.

Several problem-solving indicators can be considered from Sumarmo's (2003) exposure, as follows: a) Identify known, questioned elements and the adequacy of the required elements; b) formulate mathematical problems or develop mathematical models; Implementing strategies to solve problems (new problems and problems) within or outside mathematics; c) explaining or interpreting the results according to the original problem, and d) Using mathematics meaningfully.

There are 4 stages of problem solving according to Polya (in Alexanderson, 2000), they are as follows:

\section{Understanding the problem}

The first step in this step proposed by Polya is reading the problem and ensuring that the students clearly understand the problem posed by the teacher. In the first instance, there are several points to consider, including: (a) Are all the words used clearly understood ?; (b) What is unknown? What are the data? How is the condition?; (c) Can the student reiterate the proposed matter with; (d) Using their own words ?; (e) Is the information held by students sufficient to enable the discovery of the right solution? (f) Can drawings or find suitable notes to aid in understanding the problem? 


\section{Devising a plan}

Polya mentioned that there are many ways to solve the problem. Skill in choosing the right strategy is best learned by solving many problems. Students will find the right strategy easily if it has solved many problems. As for things that need diperhaatikan in this second stage include: a) Finding a relationship between the information provided and the unknown that will allow students to count is known. Look for links between data and unknowns; b) Have the students ever seen it before? Or have students seen the same problem in a slightly different form ?; c) Does the student know the related problem? Does the student know the useful theorem ?; d) Try to think about common problems.

\section{Carrying out the plan}

This step is usually easier than composing a plan. In general, what is needed is attention and patience, given that students have the skills provided. Do exactly the plan that has been prepared. If it turns out this plan is not right because it can not find the right solution, then choose another plan. Do not despair first, because that's how to solve math. The thing to be aware of at this stage is that students can see clearly that the steps they are doing are right? Can students prove that is true?

\section{Looking back}

Polya mentions that much can be gained by contemplating and looking back at what these students have done. Important things that can be developed in this last step include: finding the possibility of generalization, checking the results obtained, finding other ways to solve the same problem, looking for other possible solutions, and in reviewing the problem solving process that has been Created. Students are expected to be able to use the complete and appropriate sentence to conclude it after knowing that the answer is correct. Doing this will allow students to predict what strategies are being used to solve problems in the future. Thinking or reviewing the steps that have been done in problem solving is a very important activity to improve the ability of children in problem solving

In addition to problem-solving skills, the ability to think logically is also an important aspect for students in learning mathematics. The ability to think logically (reasoning), namely the ability to find a truth based on certain rules, patterns or logic (Suriasumantri 2009). This capability needs to be developed in mathematics learning, as it can help students to improve their math comprehension skills (Priatna 2003). From here it can be said that the effort to improve logical thinking ability can bridge on improving students' mathematics learning outcomes through a correct understanding of the concept of mathematical concepts.

Albrecht 1992 (in Saragi, 2011) explains that in the process of thinking one must depart from the logical prologue, namely: (a) the ground of thought or reality of footing, (b) argumentation or the way of putting together common ground, and (c) Which is achieved by applying arguments on the rationale. In mathematics, the process of obtaining truth or the process of drawing conclusions can be done by inductive and deductive thinking.

Inductive thinking or induction is defined as a thought process to draw a conclusion from the particular to the general, Sumarmo (in Saragi, 2011). The 
particular thing in question can be either a few premises or antecedents, while the general thing is a conclusion or conclusion. This means that the inductive thinking process begins by examining the premises given to obtain a perception of the pattern or order, and the similarity in order to obtain a conclusion. Because the decision-making process is based on the pattern, it is possible that the conclusion obtained is wrong. Sumarmo (in Saragi, 2011) says that inductive thinking relates to the truth of probabilistic conclusions.

Saragih (2006) reveals that logical thinking has a difference with memorization. Memorization refers only to the achievement of mere memory, whereas logical thinking refers more to understanding understanding, application ability, analytical ability, synthesis ability, and even evaluation ability to form proficiency (a process). According to Albrecht (2009) in audiblox (Logical Thinking: A Learned Mental Process) menyatakan bahwa; "logical thinking is the process in which one uses reasoning consistently to come to a conclusion. Problems or situations that involve logical thinking call for structure, for relationships between facts, and for chains of reasoning that "make sense." "Logical thinking is a process in which the use of reasoning is consistent to take a conclusion. Problems or situations involving logical thinking expect structure, the relationship between facts, and connecting "understandable" reasoning.

Logical thinking is closely related to problem solving. The ability to think logically is required by the individual, at the time of decision making, drawing conclusions, and solving problems. The form of activity performed can be related to mathematical problems and problems found in everyday life. Another activity that individuals do in logical thinking is to explain why and how a result is obtained, how to draw conclusions from available premises, and draw conclusions based on certain inference rules. A wider form of activity than logical thinking is a reasonable problem solving.

Open-ended problem solving requires a complete and systematic thought process of the student, that is, in raising the right answers or raising the various ways that lead to one true answer to the problem. Therefore, in learning mathematics lecturers need to know the thinking process of students in solving problems, helping students to solve open problems, and develop student skills in monitoring and evaluating his own thoughts when solving problems.

Some previous research finding explain that the relationship between logical thinking with problem solving such as Bancong, 2013 with the results of research that logical reasoning profiles of learners who have a thinking style impact on the ability to solve Physics problems. Maharani, 2013 with the results of research that (1) Thinking logical students in understanding, planning, completing and re-examining the results obtained, high-ability students in the analysis phase to divide the problem into the element or sub-issue has a good tendency. Meanwhile, moderate and low-ability students tend to be enough, (2) Thinking logical students in understanding, planning, completing and reexamining the results obtained, high-ability students at the stage of analysis make thinking diagram has a good tendency, while the students are moderate and low in stage (3) Student logical thinking in planning, completing and reexamining the results obtained, high-ability students in the analysis phase to collect factors have a good tendency, students are moderate enough, and low- 
ability students less tendency, (4) Student's logical thinking in planning, completing and re-examining the results obtained, high-ability students, medium and low in the analysis phase of looking for relationships have a good tendency, (5) logical thinking of students in planning (6) Student logical thinking in completing and re-examining the results obtained, high and middleskilled students at the stage of analysis of conclusions Has enough inclination. Meanwhile, low-skilled students tend to be less, (7) Student logical thinking in understanding, planning, completing and re-examining the results obtained, high-ability and moderate students in the analysis phase of systematic steps have enough trends. Meanwhile, low-ability students have less tendency.

The number of problems about the low ability of student problems is expressed by some previous research. This is in accordance with Kilpatric revelation (Nelvin, 2012) even though students have the required concepts and skills, but students are not always successful in solving math problems. Similarly, Siswono (2006) explains one of the problems in learning mathematics is the low ability of students in solving non-routine problems or open problems. One of the factors causing students ability in problem solving is in planning problem solving not discussed various strategies to get answer problem.

At the college level, according to CUPM (2004), students are often unaware of the importance of relationships between separate mathematical subjects and between mathematics and other disciplines. They are also surprisingly reluctant or unable to apply the knowledge they gain in math lessons to other disciplines.

But in reality, most of students find it is difficult to solve various types of problems given, especially if they have to deal with problems that are not commonly found. From the interview, the students admitted that they were confused to use the theory according to the given problem. Based on the observation of the writer of pata dated October 19, 2016, it was learned that the weakness of the students in my problem in the subject of economic mathematics is not to understand the students to be problem so that they can not identify and apply the approach and strategy to solve the problem; Another thing that is students are not able to make a mathematical modeling or less able to transfer a problem in the form of a story into a mathematical sentence, in addition to the still low mathematical knowledge of students in problem solving.

Other mistakes experienced by students in solving problems on the part of understanding the problem are habit errors and misunderstanding of problems, language interpretation errors, and symbolic errors and mathematical modeling, concert errors, principle errors, and algorithm errors. In addition, students do not master the previous concepts used in the material being studied and the lack of practice in working on logic problems so that student errors are mainly on considerable skill. Furthermore, the understanding of logical interrelationships between concepts, theories, technical aspects is less effectively emphasized so that students tend to memorize, are less creative, and have difficulty developing their cognitive abilities. (Fachrurrozie, 2009).

Understanding of the material in each course is absolutely necessary as a frame of mind to solve the problem. Face problems because they introduce something new and complex for the scope of the mathematical language for a situation or approaching economic problems. The problem affects the low 
involvement of students in teaching and learning process. The subject of Economic Mathematics has sufficiently dense material, which requires the cognitive aspect and technical math skills, so it takes practice questions, whether of a case or not. Therefore the assessment of this course is not only based on the final results of the students reflected in the value of written examinations, but more emphasis on the ability of students to perform processes in accordance with applicable normative guidelines. Assessment of student learning process based on liveliness and student involvement during lecturing, either in giving suggestion, question or argument.

\section{Research Methodology}

This research is an ex-post facto research that is causality with the number of population of 245 people from 8 different classes. The sample is taken from 59 people from 2 classes with random sampling technique in groups. The research instrument consisted of 30 logical thinking logic test and 5 problem solving test that was valid and reliable before use.

This research procedure begins with a situation analysis that leads to the formulation of the problem and the determination of the research objectives dilakjutkan with data collection through the test of problem-solving skills and logical thinking ability tests. Data analysis techniques used are descriptive statistics and inferential analysis (Regression Analysis). Descriptive analysis based on the percentage of achievement of problem solving ability and logical thinking ability with the formula:

$$
\begin{aligned}
& \text { Score percentage of each student }=\frac{\text { Amount of Each Score } X 100 \%}{\text { Number of Ideal Scores }} \\
& \text { Percentage of average scores of students }=\frac{\text { Total Percentage Score of All Students }}{\text { Number of Students }}
\end{aligned}
$$

As a guide in taking decision / conclusion from data analysis result by using percentage (\%) specified classification which also refers to opinion of Arikunto (2002) as follows.

Table 1. Percentage Criteria for Problem Solving Ability and Logical Thinking Ability.

\begin{tabular}{|c|c|l|}
\hline No & Persentase\% & \multicolumn{1}{|c|}{ Klasifikasi } \\
\hline 1 & $92-100$ & Very well \\
\hline 2 & $75-91$ & Good \\
\hline 3 & $50-74$ & Pretty good \\
\hline 4 & $25-49$ & Not good \\
\hline 5 & $0-24$ & Not good \\
\hline
\end{tabular}

Source: Arikunto (2002)

\section{Research Findıng}

The results were analyzed by two methods, namely descriptive analysis and the infrared analysis with the finding as the following table. 


\section{Descriptive Analysis Result}

Table 2. Descriptive Analysis Results

\begin{tabular}{|c|c|c|c|}
\hline \multicolumn{4}{|c|}{ Statistics } \\
\hline & & Logical Thinking X & Solution to problem Y \\
\hline \multirow{2}{*}{$\mathrm{N}$} & Valid & 58 & 58 \\
\hline & Missing & 0 & 0 \\
\hline \multicolumn{2}{|c|}{ Mean } & 69,13 & 74,03 \\
\hline \multicolumn{2}{|c|}{ Std. Error of Mean } & 1,451 & 1,472 \\
\hline \multicolumn{2}{|c|}{ Median } & 70,00 & 73,00 \\
\hline \multicolumn{2}{|c|}{ Mode } & 76,67 & 84,00 \\
\hline \multicolumn{2}{|c|}{ Std. Deviation } & 11,059 & 11,217 \\
\hline \multicolumn{2}{|c|}{ Variance } & 122,25 & 125,82 \\
\hline \multicolumn{2}{|c|}{ Skewness } & $-1,175$ &,- 093 \\
\hline \multicolumn{2}{|c|}{ Std. E. Skewness } & ,314 & 314 \\
\hline \multicolumn{2}{|c|}{ Kurtosis } & 1,68 & $-1,157$ \\
\hline \multicolumn{2}{|c|}{ Std. EE } & ,618 & ,618 \\
\hline \multicolumn{2}{|c|}{ Range } & 53,34 & 40,00 \\
\hline \multicolumn{2}{|c|}{ Minimum } & 33,33 & 52,00 \\
\hline \multicolumn{2}{|c|}{ Maximum } & 86,67 & 92,00 \\
\hline \multicolumn{2}{|c|}{ Sum } & 4010,01 & 4294,00 \\
\hline
\end{tabular}

\section{Source: Data Processed}

Furthermore, the results of logical thinking ability and problem-solving ability are classified in the following table.

Table 3. The classification of logical thinking

\begin{tabular}{|c|c|c|c|}
\hline No & Information & $\boldsymbol{f i}$ & $\%$ \\
\hline 1 & Very well & 0 & 0 \\
\hline 2 & Good & 37 & 63,79 \\
\hline 3 & Pretty good & 18 & 31,03 \\
\hline 4 & Not good & 3 & 5,17 \\
\hline 5 & Not good & 0 & 0 \\
\hline 6 & amount & 58 & 100 \\
\hline
\end{tabular}

Source: Data Processed 
Table 4. Classification of Problem-Solving Capabilities

\begin{tabular}{|c|c|c|c|}
\hline NO & Information & $\boldsymbol{f}$ & $\%$ \\
\hline 1 & Very well & 2 & 3,45 \\
\hline 2 & Good & 22 & 37,93 \\
\hline 3 & Pretty good & 34 & 58,62 \\
\hline 4 & Not good & 0 & 0 \\
\hline 5 & Not good & 0 & 0 \\
\hline 6 & Amount & 58 & 100 \\
\hline
\end{tabular}

Source: Data Processed

Table 5. Profile of interrelationship between logical thinking ability with problem solving abilities.

\begin{tabular}{|c|c|c|c|}
\hline No & Information & fi & $\%$ \\
\hline 1 & Less - Good & 1 & 1,72 \\
\hline 2 & Enough -> Good & 11 & 18,97 \\
\hline 3 & Less - Good Enough & 2 & 3,45 \\
\hline 4 & $\begin{array}{c}\text { Pretty Good - G Good } \\
\text { Enough }\end{array}$ & 24 & 41,38 \\
\hline 5 & Good - Enough & 8 & 13,79 \\
\hline 6 & Good - Good & 10 & 17,24 \\
\hline 8 & Good Enough -> Very & 2 & 3,45 \\
\hline $\mathbf{9}$ & Good & $\mathbf{5 8}$ & $\mathbf{1 0 0}$ \\
\hline
\end{tabular}

Source: Data Processed

\section{Inferential Analysis Results}

Inferential analysis with simple regression analysis method obtained results as the following table.

Table 6. Regression Analysis Results

\begin{tabular}{|c|c|c|c|c|}
\hline No & Model & \multicolumn{3}{|c|}{ Nilai } \\
\hline 1 & $\mathrm{R}$ & \multicolumn{3}{|c|}{, $945^{\mathrm{a}}$} \\
\hline 2 & R Square & \multicolumn{3}{|c|}{,893 } \\
\hline 3 & Adjusted R Square & \multicolumn{3}{|c|}{891} \\
\hline 4 & Std. EE & \multicolumn{3}{|c|}{,81784 } \\
\hline 5 & $\mathrm{~F}$ & \multicolumn{3}{|c|}{465,132} \\
\hline 6 & Sig. & \multicolumn{3}{|c|}{, $000^{\mathrm{b}}$} \\
\hline & Costant & \multicolumn{3}{|c|}{1,695} \\
\hline 8 & Ket & Beta & $\mathrm{t}$ & Sig \\
\hline 9 & Think logic $\mathrm{X}$ & 0,704 & 21,56 & 0,00 \\
\hline 9 & Jumlah & 58 & 100 & \\
\hline
\end{tabular}

Source: Data Processed 


\section{Model Summary}

- The R number of 0.945 indicates that the correlation of observed values and predictive value is quite strong.

- The $\mathrm{R}$ square number or the coefficient of determination is 0.893 . This means that the model has a predicted power of $89.3 \%$ of the $\mathrm{Y}$ variation explained by the model. It means that logical thinking ability influence $89,3 \%$ toward student problem solving ability.

- Adjusted R Square is 8.91. This means that $89.1 \%$ variation of the dependent variable can be explained by the variation of the independent variable, while the remaining $10.9 \%$ is explained by other variables outside the model.

- Standard Error of Estimate (SEE) is 0.817 The smaller the SEE will make the regression model more accurately predict the dependent variable.

The result of regression equation obtained as follows:

$\mathrm{Y}=1,69+0,704 \mathrm{X}$

\section{Discussion}

Based on the results of the study obtained the average score of logical thinking ability of 58 respondents of 69.13 or are in good enough category with information that 3 people or $5.17 \%$ how dapa category less good, 18 or $31.03 \%$ are in enough categories Well, 37 or $63.79 \%$ are in the good category, and nothing is in the bad and bad category.

The score of problem solving ability of 58 respondents average score is 74,03 or is in good enough category with information that 2 person or $3,45 \%$ how dapa category is very good, 22 or $37,93 \%$ are in good category, 34 Or $58.62 \%$ are in good enough, and no one is in the category of less good and not good.

Furthermore from the results of correlation analysis obtained Pearson Correlation value of 0.945 with sig value. $=0.000<0.05$ it means that the ability to think logically has a correlation with the ability to solve math problems with a $94.5 \%$ relationship where it is in very good category. Furthermore the results of descriptive analysis can be explained that from 58 students there are 1 person or $1.72 \%$ students who have logical thinking ability are in the category of less good but have problem solving ability is in good category; 1 person or $18.97 \%$ of students who have logical thinking ability are in good enough category but have problem solving ability is in good category; 2 people or $3.45 \%$ of students who have logical thinking ability are in the less good category but have problem solving ability is in good enough category; 24 people or $41.38 \%$ of students who have logical thinking ability are in good enough category but problem solving ability is also in good enough category; 8 people or $13.79 \%$ of students who have logical thinking ability are in good category but problem solving ability is also in good enough category; 10 people or $17.24 \%$ of students who have logical thinking ability are in good category and problem solving ability is also in good category; And 2 or $3.45 \%$ of students who have logical thinking ability are in good enough category but have problem solving ability is in very good category.

Furthermore, the ability to think logically has a positive effect on problem solving ability with influence of $89.1 \%$ while the rest of $10.9 \%$ is influenced by other variables outside the model. The ability to think logically has a positive 
effect on the ability of completion ability, it can be interpreted that the better or the higher the logical thinking ability possessed by the student then the ability of problem solving student will be better or higher.

It is the basis that the ability to think logically is very important possessed by students, further explained that people who can solve problems in complex have enough reasoning and logical reasoning. Logical thinking is capable of questioning the process of evaluation embodied in problem solving (Nazan, 2011). Logical thinking is one of the ways used to acquire sophisticated mental activity. Thus, ability is an application-level activity that depends on the level of goal knowledge and understanding, logical thinking in evaluating ideas, information and experiences.

This research finding of this study in line with the results of research Bancong, 2013 with the results of research that logical reasoning profiles of learners who have a thinking style impact on the ability to solve the problem Physics. Maharani, 2013 with the results of research that (1) Thinking logical students in understanding, planning, completing and re-examining the results obtained, high-ability students in the analysis phase to divide the problem into the element or sub-issue has a good tendency. Meanwhile, moderate and lowability students tend to be enough, (2) Thinking logical students in understanding, planning, completing and re-examining the results obtained, high-ability students at the stage of analysis make diagrams think have a good tendency, while students are moderate and low in stage The analysis makes the thinking diagram has enough inclination.

Logical thinking is closely related to problem solving. The ability to think logically is required by the individual, at the time of decision making, drawing conclusions, and solving problems. The form of activity performed can be related to mathematical problems and problems found in everyday life. Another activity that individuals do in logical thinking is to explain why and how a result is obtained, how to draw conclusions from available premises, and draw conclusions based on certain inference rules. A wider form of activity than logical thinking is a reasonable problem solving.

Through structured problem solving, the students are expected to gain and obtain experience in explaining each step or mathematical manipulation they use. By encouraging the student mental involvement in depth in problemsolving activities, students students are expected to develop their reasoning (Scusa \& Yuma, 2008).

The results of this study support the 1994 Munro theory which explains that mathematical logical thinking ability is an understanding by using abstract concepts and symbols such as mathematical symbols and reasoning. Students build ideas using inductive and deductive reasoning. They are looking for logical reasons, regularity and consistency, the ways ideas organized or related to, for example, cause and effect. They analyze patterns, make observation goals, draw conclusions and formulate hypotheses and apply common rules to specific situations. They easily understand and use mathematical formulas, and they prefer organized and logical things.

This confirms that mathematical logical thinking is closely related to reasoning, both inductive and deductive. In addition, the mathematical logical 
thinking ability is also very influential on the conclusion, and apply the general rule (generalization), which all include the indicators of mathematical reasoning ability.

Furthermore according to the previsous theories in line with the results of this study is Campbell (2006: 40) which states that the ability to think logically involves many components, among others, as follows: (1) mathematical calculations; (2) think logically; (3) problem solving; (4) deductive and inductive considerations; And (5) the sharpness of patterns and relationships. And Hoerr's theory (2007: 18) which states that students who have logical thinking ability like the following things are as follows: (1) Working with numbers; (2) solve the problem; (3) analyze the situation; (4) understanding how things work; And (5) shows the correctness in solving the problem.

\section{Conclusion}

Based on the results of research, then drawn conclusion as follows:

1. The level of logical thinking ability of the masses is in good enough category with an average score of 69.13 .

2. The level of problem solving ability of economic mathematics for the student is in good enough category with average value 74,03 .

3. The level of logical thinking ability of the students has a correlation with the ability to solve economic math problems with a $94.5 \%$ relationship where it is very good.

4. The results of descriptive analysis can be explained that from 58 students there are 1 person or $1.72 \%$ students who have logical thinking ability is in the category of less good but has problem solving ability is in good category; 1 person or $18.97 \%$ of students who have logical thinking ability are in good enough category but have problem solving ability is in good category; 2 people or $3.45 \%$ of students who have logical thinking ability are in the less good category but have problem solving ability is in good enough category; 24 people or $41.38 \%$ of students who have logical thinking ability are in good enough category but problem solving ability is also in good enough category; 8 people or $13.79 \%$ of students who have logical thinking ability are in good category but problem solving ability is also in good enough category; 10 people or $17.24 \%$ of students who have logical thinking ability are in good category and problem solving ability is also in good category; And 2 or $3.45 \%$ of students who have logical thinking ability are in good enough category but have problem solving ability is in very good category.

The ability to think logically has a positive effect on problem solving ability with influence of $89.1 \%$ while the rest of $10.9 \%$ is influenced by other variables outside the model. The ability to think logically has a positive effect on the ability of completion ability, it can be interpreted that the better or the higher the logical thinking ability possessed by the student then the ability of problem solving student will be better or higher.

\section{Disclosure statement}

No potential conflict of interest was reported by the authors. 


\section{Notes on contributors}

Wahyuddin - Faculty of Teacher Training and Education, University of Muhammadiyah Makassar, Makassar, South Sulawesi Indonesia

\section{References}

Albrecht, K. (2009). Logical Thinking: http://www.audiblox2014.com/.

Alexander, K.D. (2007). Effect of Intruction in Creative Problem Solving on Cognition, Creativity, and Satisfaction among Ninth Grade Students in An Introduction to World Agricultural Science and Technology Course. Dissertation. The Graduate Faculty of Texas Teach University. (Online) Tersedia: http://www.scirus.com.

Arikunto, Suharsimi. (2002). Prosedur Penelitian Suatu Pendekatan Praktek. Jakarta: PT. Rineka Cipta.

Bancong, H. (2013). Profil Penalaran Logis Berdasarkan Gaya Berpikir dalam Memecahkan Masalah Fisika Peserta Didik. Jurnal Pendidikan IPA Indonesia. 2 (2), hlm. 195-202. ISSN: 2339-1286. Diakses di http ://journal.unnes.ac.id /nju/index.php/jpii.

Cambell, Linda. (2006). Metode Praktis pembelajaran Berbasis Multiple Intelligences. Depok : Insuisi Press.

CUPM (2004). Undergrad uate Program and Course in the Mathematical Sciences: CUPM Curriculum Guide. The Mathematical Association of America.

Departemen Pendidikan Nasional. (2005). Undang-Undang Nomor 14 Tahun 2005, Tentang Guru dan Dosen, Jakarta: Depdiknas.

Fachrurrozie. (2009). Eams Games Tournament Sebagai Upaya Peningkatan Kemampuan Belajar Mahasiswa Pada Mata Kuliah Matematika Ekonomi. Jurnal Pendidikan Ekonomi. 4 (1), hlm. 51-68. ISSN: 2541-562X. Diakses di http://id.portalgaruda.org/?ref=browse\&mod=viewarticle\&article=136358.

Hoerr, Thomas. R. (2007) Buku Kerja Multiple Intelle Gences : Pengalaman New City School di St. Louis, Missouri, As, Dalam Menghargai Aneka Kecerdasan Anak. Bandung : Mizan Media Utama.

Kisworo, A. (2000). Pembelajaran Pemecahan Masalah pada Pembelajaran Geometri di Kelas I SMU Petra 5 Surabaya. Tesis. Surabaya : PPS Universitas Negeri Surabaya.

Matlin, M.W. (2003). Cognition. Fifth Edition. New York : John Wiley \& Son.Inc

Maharani, Swasti. (2013). Profil Berpikir Logis Mahasiswa Calon Guru Matematika dalam Menyelesaikan Luas Daerah dengan Menggunakan Integral Lipat Dua. Jurnal Ilmiah Pendidikan Matematika. 2 (1), hlm. 1-6. ISSN : 2301-7929. Diakses di http://ejournal.ikippgrimadiun.ac.id/index.php/jipm/index.

Nazan, Sezen, (2011). A scale on logical thinking abilities. Procedia Social and Behavioral Sciences. 15 (2011), hlm. 2476-2480

NCTM. (2000). Principles and Standards for School Mathematics . Virginia: NCTM, Inc

Nelvin, Nool. R. (2012). Effectiveness of an Improvised Abacus in Teaching Addition of Integers. Journal of International Conference on Education and Management Innovation IPEDR..30 (2012), hal 307-311. Diakses di http://www.ipedr.com/vol30/60-ICEMI\%202012M10060.pdf.

Priatna, N. (2003). Kemampuan Penalaran dan Pemahaman Matematika Siswa Kelas 3 Sekolah Lanjutan Tingkat Pertama Negeri di Kota Bandung. Disertasi Doktor. PPS UPI Bandung: tidak diterbitkan.

Ruseffendi, E.T. (2006). Pengantar Kepada Membantu Guru Mengembangkan Kompetensinya dalam Pengajaran Matematika untuk Meningkatkan CBSA. Bandung: Tarsito.

Saragih, Sahat. (2006). Menumbuhkembangkan Berpikir Logis dan Sikap Positif terhadap Matematika Melalui Pendekatan Matematika Realistik. Jurnal pendidikan dan 
kebudayaan Departemen Pendidikan Nasional. Badan Penelitian dan Pengembangan, Edisi Juli 2006.

Saragih, S. (2011). Menumbuh Kembangkan Berpikir Logis dan Sikap Positif Terhadap Matematika Melalui Pendekatan Matematika Realistik. Diakses di. www. Scribd. Com/ doc /4674 9184/aretical. Diakses pada 15 Oktber 2016.

Scusa, T. and Yuma, C.O. (2008). Five Processes Of Mathematical Thinking: Math in the Middle Institute Partnership. University Of Nebraska Lincoln: Summative Projects For Ma Degree

Siswono, Tatag. (2004). Identifikasi Proses Berpikir Kreatif Siswa dalam Pengajuan Masalah (Problem Posing) Matematika Berpandu dengan Model Wallas dan Creative Problem Solving (CPS). Buletin Pendidikan Matematika. 6 (2), hlm. 1-16. Diakses di https://tatagyes.files.wordpress.com/2009/11/paper04_wallascps1.pdf.

Sumarmo, U. (2000). Pengembangan Model Pembelajaran Matematika untuk Meningkatkan Kemampuan Inteleqtual Tingkat Tinggi Siswa Sekolah Dasar. Laporan Penelitian FPMIPA IKIP Bandung. Tidak diterbitkan.

Sumarmo, U (1994). Suatu Alternatif Pengajaran untuk Meningkatkan Kemampuan Pemecahan Masalah Matematika pada Guru dan Siswa SMP. Bandung: Pendidikan Matematika FPMIPA Bandung.

Suriasumantri, J.S. (2009). Filsafat Ilmu Sebagai Pengantar Populer. Jakarta : Pustaka Sinar Harapan.

Utari, Sumarmo. (2003). Berpikir dan Disposisi Matematik: Apa, Mengapa, dan Bagaimana dikembangkan pada Siswa Sekolah Dasar dan Menengah. Bandung: ITB.

Walle, John A. Van De. (2008). Sekolah Dasar dan Menengah Matematika Pengembangan Pengajaran . Jakarta: Erlangga.

Van De Walle, John A. (2003). Pengembangan Pengajaran Matematika. Jakarta: Erlangga. 